\title{
RESEARCH
}

Case report

\section{Interaction between lopinavir/ritonavir and warfarin}

\author{
Christine A. Hughes PharmD, Andrea Freitas BSc, Lilly J. Miedzinski MD
}

$\infty$

See related articles pages 347 and 369

\section{ABSTRACT}

Drug interactions involving protease inhibitors are common. Protease inhibitors are well known inhibitors of the $3 \mathrm{~A}_{4}$ isozyme of cytochrome $\mathrm{P} 450$. Select protease inhibitors, including co-formulated lopinavir/ritonavir, may induce glucuronidation or the activity of other CYP450 isozymes. We describe the case of a patient taking warfarin who experienced a significantly decreased international normalized ratio after the initiation of antiretroviral therapy that included lopinavir/ritonavir. We review the possible mechanisms of this interaction and the reported interactions between warfarin and other protease inhibitors.

Une version française de ce résumé est disponible à l'adresse www.cmaj.ca/cgi/content/full/177/4/357/DCI

CMAJ 2007;177(4):357-9

$\mathrm{A}$ 42-year-old man was admitted to hospital with chills and progressive shortness of breath on exertion. $\mathrm{He}$ had received an aortic valve replacement 12 years before presentation and had been taking warfarin since that time. A diagnosis of pneumonia caused by Pneumocystis jiroveci was made and was confirmed by Giemsa staining of bronchoscopy specimens. Serologic testing revealed a positive HIV status, with a baseline $\mathrm{CD}_{4}$ cell count of $150 \times 10^{6} / \mathrm{L}$. The patient's pneumonia was treated with high-dose co-trimoxazole therapy and a tapering course of steroids. In addition, daily fluconazole therapy was initiated for the treatment of candidiasis, and citalopram for the treatment of depression. In the year before he was admitted to hospital, the patient had been taking warfarin $(5.5 \mathrm{mg} / \mathrm{d})$ to maintain his international normalized ratio (INR) between 2 and 3. Five days after discharge from hospital, his INR was 4.4. Warfarin was held for I dose and was then resumed at an alternating dose of $3 \mathrm{mg} / \mathrm{d}$ and 3.5 $\mathrm{mg} / \mathrm{d}$. Three days and 2 weeks later the INR was 3.8 and 2.1 respectively. Two weeks after discharge, co-trimoxazole therapy was decreased to a prophylactic dose (I doublestrength dose daily). One month after discharge, the patient was prescribed antiretroviral therapy (zidovudine, lamivudine and lopinavir/ritonavir). At that time, in addition to warfarin, he was taking co-trimoxazole, fluconazole daily, citalopram, clonazepam, zopiclone and pantoprazole. He was instructed to reduce fluconazole therapy from daily to weekly, and the co-trimoxazole therapy was decreased from double to single strength.

Following initiation of the lopinavir/ritonavir therapy, the patient's INR decreased substantially, with repeated values between I.I and I.3. At a follow-up visit I month after initiation of the lopinavir/ritonavir, the patient reported that he had continued taking fluconazole daily despite instructions to decrease it to once weekly. The fluconazole therapy was discontinued at that time, and repeat testing over the next few weeks revealed INR values between I.O and I.3. We ruled out patient nonadherence as well as changes in diet as possible explanations for the continued low INRs. The warfarin dose was titrated by his family physician over several months to a dose of II $\mathrm{mg} / \mathrm{d}$. His INR remained subtherapeutic during this period. Six months after fluconazole was discontinued his INR was 2.6. The patient was referred to the anticoagulation management service, and I month later his INR had stabilized between 2 and 3 (at a warfarin dose of about $\mathrm{I} 3 \mathrm{mg} / \mathrm{d}$ ). He continued to take antiretroviral medications, as well as the other prescribed medications, during this period. Seven months after initation of the antiretroviral therapy, the patient's $\mathrm{CD}_{4}$ cell count had risen to $330 \times 10^{6} / \mathrm{L}$, and his HIV viral load was $<50$ copies $/ \mathrm{mL}$.

\section{Comments}

Lopinavir/ritonavir (a co-formulation of lopinavir and ritonavir) is recommended as a preferred protease inhibitor for the treatment of HIV in patients who have not previously received antiretroviral therapy because it is potent, has a high genetic barrier to resistance and is tolerated by patients. ${ }^{1}$ Lopinavir is enzymatically inactivated by the cytochrome $\mathrm{P}_{4}{ }^{\circ}$ (CYP450) $3 \mathrm{~A} 4$ isozyme; however, ritonavir inhibits $\mathrm{CYP}_{3} \mathrm{~A}$ activity and thus increases the plasma concentration of lopinavir and other $\mathrm{CYP}_{3} \mathrm{~A}$ substrates. ${ }^{2}$ These drug interac-

From the Faculty of Pharmacy and Pharmaceutical Sciences (Hughes, Freitas), and the Division of Infectious Diseases, Department of Medicine (Miedzinski), University of Alberta; and Capital Health (Hughes), Edmonton, Alta. 
Table 1: Reported interactions between warfarin and protease inhibitors

\begin{tabular}{lcccc}
\hline Report & $\begin{array}{c}\text { Warfarin dose before } \\
\text { initiation of protease inhibitor }\end{array}$ & $\begin{array}{c}\text { Protease inhibitor, } \\
\text { dose at initiation }\end{array}$ & $\begin{array}{c}\text { Effect on } \\
\text { INR }\end{array}$ & $\begin{array}{c}\text { Warfarin dose required } \\
\text { to maintain therapeutic INR }\end{array}$ \\
\hline $\begin{array}{l}\text { Knoell et al, } \\
1998^{7}\end{array}$ & $12.5 \mathrm{mg} / \mathrm{d}$ & $\begin{array}{l}\text { Ritonavir, } 400 \mathrm{mg} \text { twice } \\
\text { daily }\end{array}$ & Decreased & $\sim 25 \mathrm{mg} / \mathrm{d}$ \\
$\begin{array}{l}\text { Gatti et al, } \\
1998^{8}\end{array}$ & $6.25 \mathrm{mg} / \mathrm{d}$ & $\begin{array}{l}\text { Ritonavir, } 600 \mathrm{mg} \text { twice } \\
\text { daily }\end{array}$ & Decreased & $8.75 \mathrm{mg} / \mathrm{d}$ \\
$\begin{array}{l}\text { Newshan and } \\
\text { Tsang, } 1999^{9}\end{array}$ & $10 \mathrm{mg} / \mathrm{d}$ & $\begin{array}{l}\text { Ritonavir, } 400 \mathrm{mg} \text { twice } \\
\text { daily } \\
\text { Nelfinavir, } 750 \mathrm{mg} \text { three } \\
\text { times daily } \\
\text { Saquinavir, } 600 \mathrm{mg} \text { three } \\
\text { times daily }\end{array}$ & Increased & $\begin{array}{l}\text { Ritonavir discontinued; INR } \\
\text { stabilized at warfarin dose } \\
\text { of } 15 \text { mg/d }\end{array}$ \\
\hline Darlington, $1997^{10}$ & NA & Increased & Warfarin dose decreased by 20\% \\
\hline
\end{tabular}

Note: $\mathrm{NA}=$ not available.

tions are complex, as shown by the ability of lopinavir/ritonavir to induce its own metabolism, as well as to induce the metabolism of other drugs metabolized by CYP450 enzymes or by glucuronidation. ${ }^{3}$ For example, lopinavir/ritonavir reduces the maximum concentration and systemic exposure of methadone and ethinyl estradiol. ${ }^{2}$

Warfarin also has the potential to interact with numerous medications as a result of altered protein binding and metabolism. Available as a racemic mixture, the 2 warfarin enantiomers differ pharmacokinetically and pharmacodynamically. ${ }^{4}$ Warfarin is stereoselectively metabolized by hepatic microsomal enzymes. ${ }^{5,6} \mathrm{~S}$-warfarin, the more potent form, is metabolized primarily by $\mathrm{CYP}_{2} \mathrm{C}$, and the R-isomer is metabolized by CYPIA2 and $\mathrm{CYP}_{3} \mathrm{~A}_{4} .{ }^{6}$ Given the potential for drug interactions, close INR monitoring is recommended when lopinavir/ritonavir is taken concurrently with warfarin; however, no specific information about this interaction is available. ${ }^{2,3} \mathrm{~A}$ computerized search of MEDLINE (I950-December 2006) and EMBASE (I988-January I997) using keywords including lopinavir, ritonavir, HIV protease inhibitors and warfarin did not reveal any clinical reports of this interaction.

We believe, for several reasons, that the precipitous decrease in INR observed in our patient's case was due to an interaction between warfarin and lopinavir/ritonavir. First, previous case reports have described a potential interaction between warfarin and other protease inhibitors (Table I). In 2 cases, a decrease in INR was observed after administration of ritonavir (400-60o mg twice daily), ${ }^{7,8}$ and in one case an increase in INR was observed after ritonavir (400 $\mathrm{mg}$ twice/d) was administered in addition to nelfinavir. ${ }^{9}$ An increase in INR has also been reported in a patient who received saquinavir therapy.$^{10}$ Second, we ruled out patient nonadherence and other potential explanations for the decreased INR, such as changes in diet or addition of other medications. Cotrimoxazole, citalopram and fluconazole have been shown to potentiate the effects of warfarin, ${ }^{11}$ and the administration of these drugs probably accounted for the increased INR seen before initiation of the lopinavir/ritonavir therapy. The patient had been taking co-trimoxazole (double strength daily) for about 2 weeks before the initiation of antiretroviral drugs, and his INR had been within the therapeutic range during that time. The co-trimoxazole therapy was reduced to single strength; however, the dose of the patient's other medications remained the same as before the decrease in INR. The warfarin dose that was required to maintain the patient's INR in the therapeutic range after the initiation of the lopinavir/ritonavir therapy was higher than the maintenance dose he had been taking in the year before his HIV diagnosis (about I $3 \mathrm{mg}$ v. $5.5 \mathrm{mg}$ ). Finally, recent evidence supports a pharmacokinetic basis for the interaction between lopinavir/ritonavir and warfarin and suggests that lopinavir/ritonavir therapy results in modest induction of CYPIA2 and $\mathrm{CYP}_{2} \mathrm{C}_{9}$ activity. ${ }^{12,13}$ Pharmacokinetic analysis using phenotyping methods in healthy participants found that io days of lopinavir/ritonavir therapy resulted in a $43 \%$ increase in CYPIA2 activity and a $29 \%$ increase in $\mathrm{CYP}_{2} \mathrm{C} 9$ activity (as measured by S-warfarin exposure). ${ }^{12}$ The increased enzymatic activity of $\mathrm{CYP}_{2} \mathrm{C} 9$ and CYPIA2 induced by lopinavir/ritonavir may reduce S- and Rwarfarin levels, thus accounting for the reduction in INR and the increased warfarin dose required to maintain the patient's INR in the therapeutic range.

The decrease in INR and the subsequent need for adjustment of the warfarin dose after initiation of lopinavir/ ritonavir therapy suggests that clinicians should be aware of the potential interaction and should closely monitor the patient's INR when these drugs are coadministered. This report highlights the complexity of drug interactions involving protease inhibitors and how our understanding of the differential effects of protease inhibitors on CYP 450 isozymes is evolving.

This article has been peer reviewed.

Competing interests: None declared for Andrea Freitas and Lilly Miedzinski. Christine Hughes has received speaker fees from Abbott Laboratories and Bristol-Myers Squibb and travel assistance from GlaxoSmithKline and Pfizer.

Contributors: Christine Hughes conducted the literature review of warfarin and protease inhibitor interactions. All of the authors were involved in the analysis and interpretation of the literature. Christine Hughes and Andrea Freitas were the principal authors, and all of the authors critically revised the article for important intellectual content. All of the authors approved the final version of the article for publication. 


\section{REFERENCES}

I. Department of Health and Human Services (DHHS) Panel on Antiretroviral Guidelines for Adults and Adolescents. Guidelines for the use of antiretroviral agents in $H I V-I$ infected adults and adolescents. Bethesda (MD): National Institutes of Health; 2006. Available: http://aidsinfo.nih.gov/contentfiles/AdultandAdolescentGL.pdf (accessed 2007 Apr 17).

2. Cvetkovic RS, Goa KL. Lopinavir/ritonavir: a review of its use in the management of HIV infection. Drugs 2003;63:769-802.

3. Kaletra drug monograph. In: Repchinsky C, editor. Compendium of pharmaceuticals and specialties, online version (e-CPS). Ottawa: Canadian Pharmacists Association; 2006 (accessed 2006 July II).

4. Niopas I, Toon S. Aarons, Rowland M. The effect of cimetidine on the steady-state pharmacokinetics and pharmacodynamics of warfarin in humans. Eur J Clin Phar macol 1999;55:399-404.

5. Warfarin drug monograph. In: Repchinsky C, editor. Compendium of pharmaceuticals and specialties, online version (e-CPS). Ottawa: Canadian Pharmacists Association; 2006 (accessed 2006 July II).

6. Ufer M. Comparative pharmacokinetics of vitamin K antagonists. Clin Pharmacokinet 2005;44:1227-46.

7. Knoell KR, Young TM, Cousins ES. Potential interaction involving warfarin and ritonavir. Ann Pharmacother 1998;32:1299-302.
8. Gatti G, Alessandrini A, Cemera $M$, et al. Influence of indinavir and ritonavir on warfarin anticoagulant activity. AIDS I998;I2:825-6.

9. Newshan G, Tsang P. Ritonavir and warfarin interaction. AIDS I999;13:1788-9.

Io. Darlington MR. Hypoprothrombinemia during concomitant therapy with warfarin and saquinavir [letter]. Ann Pharmacother 1997;31:647.

II. Holbrook AM, Pereira JA, Labiris R, et al. Systematic overview of warfarin and its drug and food interactions. Arch Intern Med 2005;165:1095-106.

I2. Yeh RF, Gaver VE, Patterson KB, et al. Lopinavir/ritonavir induces the hepatic activity of cytochrome $\mathrm{P}_{450}$ enzymes $\mathrm{CYP}_{2} \mathrm{C}_{9}, \mathrm{CYP}_{2} \mathrm{C}_{19}$, and $\mathrm{CYP}_{2} \mathrm{~A}_{2}$ but inhibits the hepatic and intestinal activity of $\mathrm{CYP}_{3} \mathrm{~A}$ as measured by a phenotyping drug cocktail in healthy volunteers. J Acquir Immune Defic Syndr 2006;42:52-6o.

I3. Lim ML, Min SS, Sherene S, et al. Coadministration of lopinavir/ritonavir and phenytoin results in two-way drug interaction through cytochrome P-450 induction. J Acquir Immune Defic Syndr 2004;36:1034-40.

Correspondence to: Dr. Christine A. Hughes, Faculty of Pharmacy and Pharmaceutical Sciences, 3126 Dentistry/Pharmacy Centre, University of Alberta, Edmonton $A B$ T6G 2N8; fax 780 492-I2I7; chughes@pharmacy.ualberta.ca 